\title{
ランダム波動のフラクタルスペクトル構造
}

\author{
東北大学理学部地球物理学教室* 小 山順 二 \\ 東北大学工学部基礎工学教室* 原啓 明
}

\section{Fractal Spectrum Structure of Random Time Series}

\author{
Junji Koy Ama \\ Geophysical Institute, Faculty of Science, Tohoku University, Aramaki-aza Aoba, Sendai 980
}

Hiroaki HaRA

Department of Engineering Science, Faculty of Engineering, Tohoku University, Aramaki-aza Aoba, Sendai 980

(Received November 1, 1988; Accepted January 23, 1989)

\begin{abstract}
A theoretical study has been made to derive the energy spectrum of random-pulse time-series. Since the pulse width corresponds to a rupture time of a random fault patch, the random time-series approximates short-period seismic radiation from the heterogeneous faultings. Assuming exponentially decaying pulses, a parameter $S$ is introduced as the inverse of pulse relaxation times. Energy spectra of the random time series are expressed by a Lorentzian-like spectrum of $1 /\left(\omega^{2}+S^{2}\right)$ with a weighting function $P(S)$, where $\omega$ is angular frequency. Cases that $P(S)$ represents the probability density for Gaussian, uniform, and power-law distributions are studied. It is found that the power-law distributions are related to the probability density distribution specified by the Cantor set. Spectra converge respective constant values at the low frequency end, whereas in high frequencies they show the $\omega^{-2}$ decay. The energy spectrum for the Gaussian is described by the Lorentzian with a spectral corner frequency of the mean value of $S$. Linear and quadratic power-law distributions of $S$ suggest the Lorentzian-like energy spectra. Fractal spectrum is obtained from the uniform distribution and distributions specified by the Cantor set, showing the $1 / f$ and $1 / f^{1+\delta}$ spectra, where $f$ is the frequency and $\delta$ is a small fractional number between 0 and 1 . The fractional power of spectral decay is related to the variance of the probability distribuition.
\end{abstract}

\section{1.はじめに}

大きな地震が励起する短周期の地震波はランダムな位 相を持つ波群であることが知られている [KoYAMA and

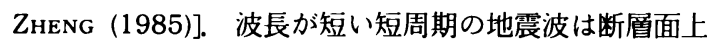
に分布する不均質な小領域（断層パッチ）のランダムな 破壊によって発生すると考えられている[例えば, 小山 (1983)]. この破壊素片をともいうべき断層パッチが巨 大な地震発生の断層運動を担っている. したがって, 短 周期の地震波が持つ統計的な性質を調べることで, 散在 する断層パッチの破壊がどのようにネットワークを作 り, 全体の断層破壊面を形成しているのかといった破壊 過程の物理的性質を知ることができる.

* 于980 仙台市荒巻字青葉
微細な素過程がマクロな現象へ発展していくプロセス は, 地震の震源過程ばかりではなく, 多くの物理現象に みられる. 近年, 特徴的な時間を持たない素過程からな る現象の性質をフラクタルと呼んでいる.コロイド粒子 の凝集過程, ランダム媒質中の輸送過程, 地表面の形態 や宇宙の見かけの構造など，いろいろな自然現象がフラ クタルの考えを用いて研究されている[高安・他 (1987)].

ここではフラクタル構造を示す静的な特性ではなく， ランダムな性質を持つ過渡的な物理現象を考える.いろ いろなランダム時系列で表現される事象により発生する 波動を考え, それらのエネルギースペクトルを調べる. 特に, $1 / f$ や $1 / f^{1+\delta}$ スペクトル構造とカントール集合型 待ち時間分布で発生する波動のスペクトル構造の関係を 詳しく調べる.これらの解析から, 地震波の震源スペク 


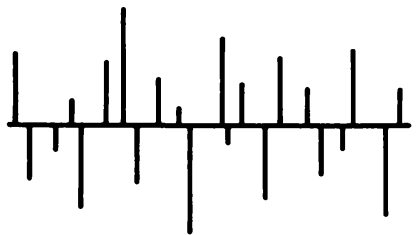

Random Impulses

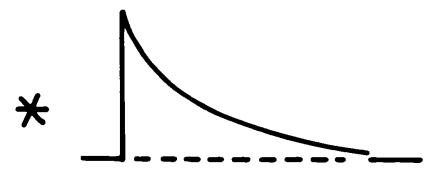

Random Decay

Fig. 1. Schematic model of random time series. Positive and negative random impulses are equally probable. And the impulses generate pulses which decay in a random manner. Thus, the time series are characterized by zero mean and random phases. The randomness of pulse relaxation coefficients is specified by the probability density in Fig. 2.

トル構造とそれが起因する断層不均質領域（断層パッ チ)の破壊過程 [小山(1988a)] の理解を深めることにす る.

\section{2.ランダムな時系列のスペクトル表現}

$1 / f$ ノイズのモデル化においては， ランダムなインパ ルスにより波動が励起され，その振幅は指数関数的に減 衰する時系列の研究が行われている [AGU and KINOSHITA (1977), 大内 (1988)]。ここではこれらのパルス時 系列を一般化して，ランダム時系列のスペクトル構造を 物理的により厳密に考える. 時系列はランダムパルスか ら構成されているものとする. 各パルスの減衰定数がパ ルスごとに異なる場合, 非常に複雑な時系列が生じる (Fig. 1). $i$ 番目のインパルスで $A_{i}$ の振幅, $S_{i}$ の減衰定 数を持つパルスが立つとする． $t_{i}$ をパルスの発生時とす れば，考える時系列は，

$$
f(t)=\sum_{i} A_{i} \exp \left\{-S_{i}\left(t-t_{i}\right)\right\} H\left(t-t_{i}\right)
$$

で表される.ここで, $H(t)$ は単位階段関数を示す. 減衰 定数 $S_{i}$ はパルスの緩和時間の逆数で定義される. $A_{i}$ は, 正と負になる確率が等しく, 平均がゼロ, 自乗平均振幅 が $\overline{A^{2}}$ で特徵づけられるものとする． $t_{i}$ の時間間隔がラ ンダムであれば, $f(t)$ はランダムな位相をもつ時系列 [Koyama and Shimada (1985)] となる.

このようなランダム波動の性質は, 不均質な断層の破 壊により発生する短周期地震波に見いだされている [KоyамA (1985)]. $A_{i}$ を変位インパルスと考えれば，そ の振幅は断層面の不均質領域（断層パッチ）の応力降下 量のゆらぎに直接関係する [Koyama and IzUTANI (1988)]. 断層面上でランダムな不均質性を考えれば, $A_{i}$ は互いに独立な確率変数となる． $S_{i}$ は断層パッチの破壊 継続時間の逆数と考えればよい [KOY AMA (1985)]. 断層 パッチの大きさがランダムであれば，その破壊継続時間 あランダムな変数として取り扱えるだろう． $S_{i}$ は断層 パッチのサイズ分布から， $A_{i}$ は断層パッチの不均質の強
さ分布から決まる確率変数と考えればよい.

$f(t)$ のフーリエ変換 $F(\omega)$ は,

$$
\begin{aligned}
F(\omega) & =\int_{-\infty}^{\infty} f(t) \exp (-i \omega t) d t \\
& =\sum_{i} A_{i} \exp \left(-i \omega t_{i}\right) /\left(i \omega+S_{i}\right)
\end{aligned}
$$

ただし， $\omega$ は角周波数である. 今後特に断わらない限り, 周波数はすべて角周波数で表されている。，そして，エネ ルギースペクトル $E_{\mathrm{t}}(\omega)$ は, (2) 式の複素共役を用いて,

$$
\begin{aligned}
E_{\mathrm{t}}(\omega)= & F(\omega) \cdot F(\omega)^{*} \\
= & \sum_{i} \sum_{j}\left\{A_{i} \exp \left(i \omega t_{i}\right)\right\}\left\{A_{j} \exp \left(-i \omega t_{j}\right)\right\} \\
& \div\left(i \omega+S_{i}\right)\left(-i \omega+S_{j}\right)
\end{aligned}
$$

となる.ランダム位相の仮定から, 任意の値 $B_{i}(=$ $\left.A_{i} /\left(i \omega+S_{i}\right)\right)$ に対して,

$\sum_{j} B_{i} B_{j} \exp \left\{i \omega\left(t_{i}-t_{j}\right)\right\}=B_{i}^{2}$

であるから，(3) 式は，

$$
E_{t}(\omega)=\sum_{i} A_{i}^{2} /\left(\omega^{2}+S_{i}^{2}\right)
$$

と表せる.

振幅 $A_{i}$ で立ち上がる 1 個のパルスが持つ全エネル ギーは,

$$
\int_{0}^{\infty} A_{i}^{2} \exp \left(-2 S_{i} t\right) d t=A_{i}^{2} / 2 S_{i}
$$

である. 時系列全体はパルスの緩和時間に比べて充分に 長く, 定常であると仮定しょう。その意味は有限な時系 列の両端で完全には含まれないパルスを無視するが，そ の影響は小さいこと, さらに, 時系列の統計的な性質が 時間によって変化しないことである. $A_{i}$ と $S_{i}$ は互いに 独立であるから, 時系列のパワー $\varepsilon$ は, 単位時間に平均 $n$ 個のインパルスが観測されるとして, 定常性の仮定か ら,

$$
\varepsilon=\sum_{i=1}^{n} A_{i}^{2} / 2 S_{i} \sim \overline{A^{2}} \sum_{i=1}^{n}\left(2 S_{i}\right)^{-1}=\mathrm{constant}
$$

と考えてよいだろう. $\overline{A^{2}}$ は先に述べたインパルスの自 乗平均振幅である. 地震現象を含む多くの物理現象は過 渡的な現象であり, 総エネルギーが有限で, その時系列 


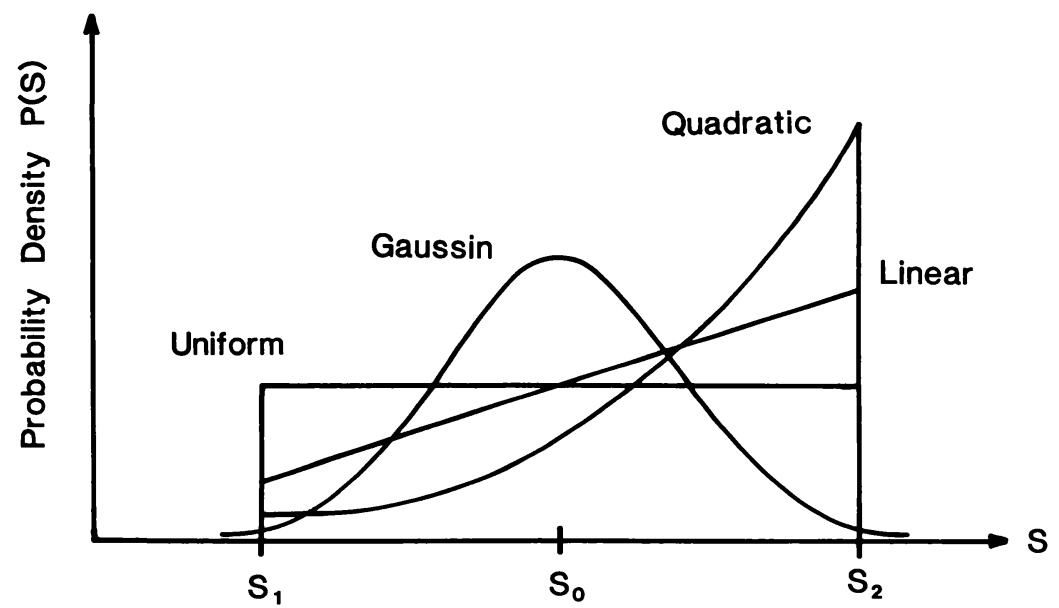

Fig. 2. Probability density for the pulse relaxation coefficient. Gaussian, uniform, and linear and quadratic power-law distributions of relaxation coefficients are considered in detail.

は有限の継続時間 $T_{0}$ をむつ. したがって, $0 \sim T_{0}$ の間で のみ時系列 $f(t)$ を観測することができる．この時, 時系 列全体のエネルギースペクトル (4) 式は, 総パルス数が $n T_{0}$ とすれば,

$$
E_{t}(\omega)=\overline{A^{2}} \sum_{i=1}^{n T_{0}}\left(\omega^{2}+S_{i}^{2}\right)^{-1}
$$

で表される. (7) 式から求められる周波数領域での全エ ネルギーは,

$$
\frac{1}{2 \pi} \int_{-\infty}^{\infty} E_{\mathrm{t}}(\omega) d \omega=\overline{A^{2}} \sum_{i=1}^{n T_{0}}\left(1 / 2 S_{i}\right)
$$

となり，(5) 式の総和から計算される時間領域での全エ ネルギーに一致する.

またこの有限時間 $T_{0}$ 内では, $S_{i} \rightarrow 0$ となる無限に長 い緩和時間を持つパルスは存在しない，また，観測系の 時間分解能には制約があるが，物理現象として記録され ることから, 時系列は有限個のパルスから構成され，無 限に短い緩和時間のパルスは意味を失う。したがって, 観測される時系列の減衰定数 $S$ には, 上限と下限が存在 することになる．結局，有限な継続時間 $T_{0}$ の時系列か ら計算される (7) 式のエネルギースペクトルは,

$$
E_{\mathrm{c}}(\omega)=\overline{A^{2}} n T_{0} \int_{S_{1}}^{S_{2}} P(S) /\left(\omega^{2}+S^{2}\right) d s^{*} W^{2}(\omega)
$$

と表される.ただし， $P(S)$ はパルス减衰定数 $S$ の確率密 度， $S_{1}$ と $S_{2}$ はそれぞれ観測可能な減衰定数の最小值と 最大值である. また, $W^{2}(\omega)$ は時系列が有限であること によるウインドーの効果を表す関数 [BLACKMAN and TURKEY (1958)] である:

$$
W^{2}(\omega)=\sin ^{2}\left(\omega T_{0} / 2\right)^{2} /\left(\omega T_{0} / 2\right)^{2}
$$

アステリスク記号* は $\omega$ でのたたみ込みを示す． $T_{0}$ が パルスの緩和時間に比べて非常に長い場合は，あるエネ
ルギースペクトル $G(\omega)$ に $(10)$ 式のウインドースペクト ルのたたみ込みを考えると， $T_{0} \rightarrow \infty$ のき， $G$ が有限で 定義される範井で,

$$
\int_{-\infty}^{\infty} G\left(\omega-\omega_{1}\right) W^{2}\left(\omega_{1}\right) d \omega_{1} \simeq G(\omega)
$$

である. 以後の議論では, ウインドーの効果を(11) 式で 形式的に評価することができる．したがって，いままで 考えてきた時系列が充分に長い条件とは，パルスの緩和 時間に比べて時系列の継続時間が長いことを意味し, 継 続時間内に多数のパルスが含まれていることが前提に なっている.

\section{3. 緩和時間の確率分布とエネルギースペクトル} 3.1 ガウス分布

パルスの減衰定数 $S$ の確率密度が, 平均値 $S_{0}$ ・分散 $\sigma^{2}$ のガウス分布である場合,

$$
P_{1}(S)=\exp \left\{-\left(S-S_{0}\right)^{2} / 2 \sigma^{2}\right\} /\left(2 \pi \sigma^{2}\right)^{1 / 2}
$$

を考える. この時, (9) 式のエネルギースペクトルは,

$$
E_{1}(\omega)=\overline{A^{2}} n T_{0} /\left(\omega^{2}+S_{0}^{2}\right) * W^{2}(\omega)
$$

となる.ただし，

$$
S_{1}<S_{0}, \quad \sigma \ll S_{0}, \quad S_{0}<S_{2}
$$

を仮定している (Fig. 2). $\sigma \rightarrow 0$ の極限では (12) 式はデル 夕関数 $\delta\left(S-S_{0}\right)$ となるから, (13) 式は直感的にも理解さ れる. 任意の $\sigma$ については, KoyAMA and ZHENG (1985) にしたがい，(9) 式の積分を最急降下法で実行すれば, (13) 式が得られる. (13) 式は周波数 $S_{0}$ で規定される ローレンッ型のエネルギースペクトルを表している.

(13) 式でウインドーの効果を解析的に考えると,

$$
E_{1}^{\mathrm{w}}(\omega)=\overline{A^{2}} n T_{0}\left[\frac{1}{\omega^{2}+S_{0}^{2}}+\frac{\omega^{2}-S_{0}^{2}}{S_{0} T_{0}\left(\omega^{2}+S_{0}^{2}\right)^{2}}\right.
$$




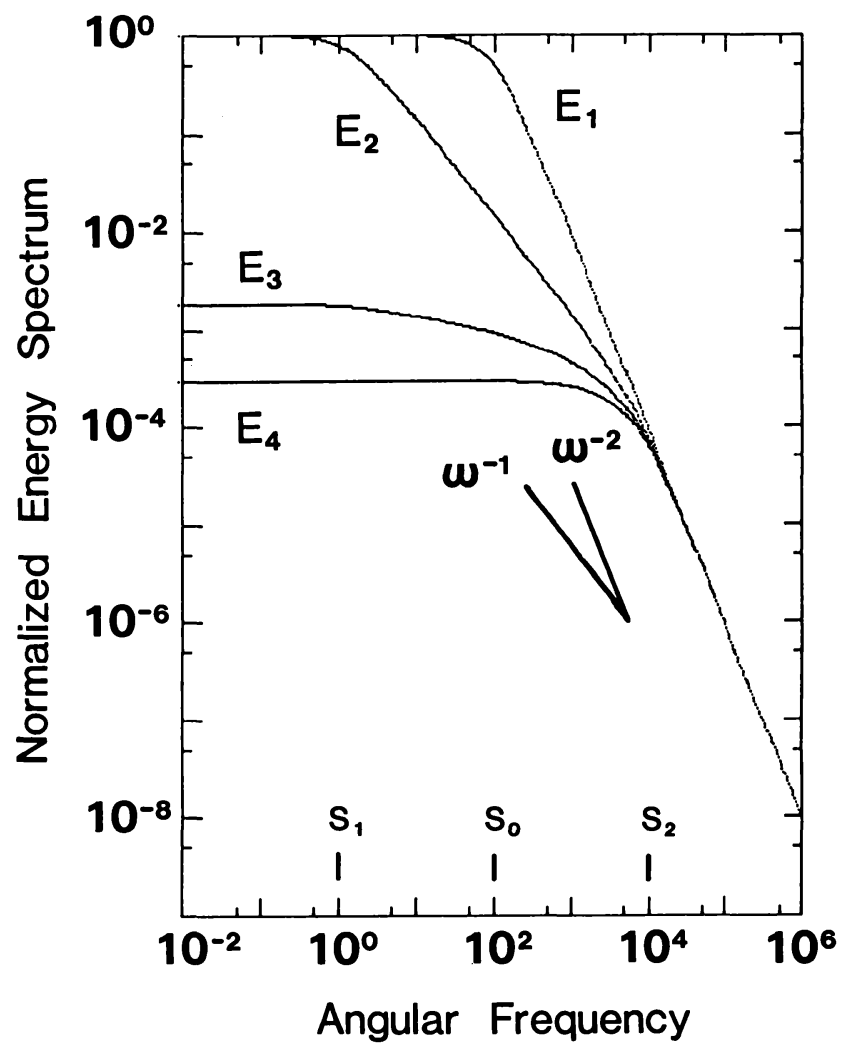

Fig. 3. Energy spectrum of random-pulse time seires from $E_{1}$ : Gaussian, $E_{2}$ : uniform, $E_{3}$ : linear, and $E_{4}$ : quadratic power distributions for the pulse relaxation coefficients. Minimum and maximum values of the coefficients are assumed to be $S_{1}=1$ and $S_{2}=10^{4}$. Mean value of the Gaussian is assumed $S_{0}=10^{2}$. The spectra are normalized by $\bar{A}^{2} n T_{0} / S_{0}^{2}$, where $\overrightarrow{A^{2}}$ is a mean squared amplitude of impulses, $n$ is an average number of impulses observable within a unit time interval, and $T_{0}$ is the time duration of random time series. Spectral decay is indicated by $\omega^{-2}$ and $\omega^{-1}$, where $\omega$ is angular frequency normalized by an arbitrary value of $S_{1}$. Clearly found is that $E_{1}$ shows a Lorentz-type energy spectrum, and it has a spectral corner frequency of $S_{0}$. The corner frequency is a frequency where the trend of spectral density changes abruptly. Two corner frequencies are found in $E_{2}$ spectrum. And they are related to $S_{1}$ and $S_{2}$. The spectral decay of $E_{2}$ in between the corner frequencies is about 1.0. $E_{3}$ spectrum decays very gradually from the corner frequency of $S_{1}$ in the low frequency range, and it also shows the other corner frequency in the high frequency range. $E_{4}$ spectrum is like as a Lorentzian spectrum with only one corner frequency of $S_{2}$ in the high frequency range. All the spectra converge on $E_{1}$ spectrum in very high frequencies.

$$
\begin{aligned}
& -\frac{\exp \left(-S_{0} T_{0}\right)}{S_{0} T_{0}\left(\omega^{2}+S_{0}^{2}\right)^{2}}\left\{\left(\omega^{2}-S_{0}^{2}\right) \cos \omega T_{0}\right. \\
& \left.\left.+2 \omega S_{0} \sin \omega T_{0}\right\}\right]
\end{aligned}
$$

となる. $S_{0} T_{0} \gg 1$ の近似を考慮すると, 大括弧の初項の みがのこり, (11) 式に一致する.

\section{2 一様分布}

次にパルスの減衰定数 $S$ の確率密度が, 2 つの定数 $\mathrm{S}_{2}$ と $\mathrm{S}_{1}$ で規定される区間で一様分布である場合を考え る (Fig. 2):

$$
P_{2}(S)=1 /\left(S_{2}-S_{1}\right) \quad\left(S_{2}>S_{1}\right)
$$

この場合，(9) 式のエネルギースペクトルを評価すると，

$$
\begin{aligned}
E_{2}(\omega)= & \frac{\overline{A^{2} n T_{0}}}{S_{2}-S_{1}} \frac{1}{\omega}\left[\tan ^{-1} S_{2} / \omega\right. \\
& \left.-\tan ^{-1} S_{1} / \omega\right] * W^{2}(\omega)
\end{aligned}
$$

となる. 時系列が充分に長く, ウインドーの効果が無視 できるとき, $\omega \rightarrow 0$ では,

$$
E_{2} \rightarrow \overline{A^{2}} n T_{0} / S_{1} S_{2}
$$

の一定値となり, $\omega \gg 1$ のときは,

$$
E_{2}(\omega) \simeq \overline{A^{2}} n T_{0} / \omega^{2}
$$

で表される. すなわち, 低い周波数帯では平坦なスペク トル, そして, 高い周波数帯では $\omega^{-2}$ で咸少するエネル 


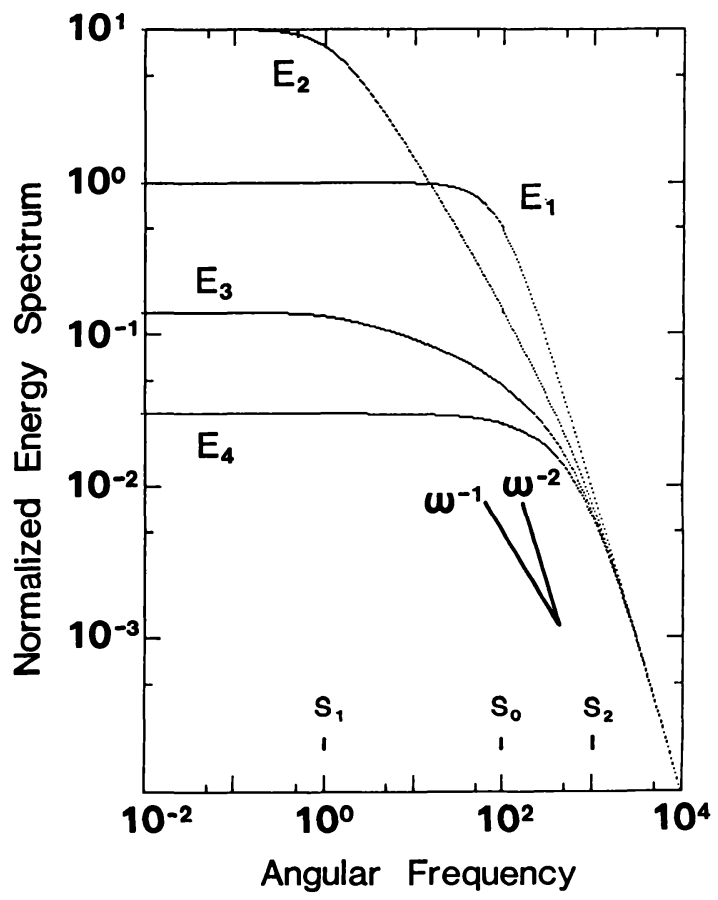

Fig. 4. Energy spectrum of the random-pulse time series. The maximum relaxation coefficient of $S_{2}$ is assumed $10^{3}$. All the others are the same as those in Fig. 3. Note that the spectral decay of $E_{2}$ in between two corner frequencies is a little larger than 1.0, showing the fractal energy spectrum.

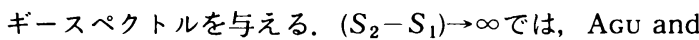
KINOSHITA (1977) が示した $E_{2}(\omega)$ の $\omega^{-1}$ となるふるま いに一致する.

\section{3 へき分布}

$S$ の確率密度がある区間 $\left[S_{1}, S_{2}\right]$ で確率変数のべき乗 で与えられる場合を考える：

$$
P_{r}(S)=(r+1) S^{r} /\left(S_{2}^{r+1}-S_{1}^{r+1}\right) \quad(r \neq-1)
$$

例えば, $r=1$ の時, (9) 式のエネルギースペクトルは,

$$
E_{3}(\omega)=\frac{2 \overline{A^{2}} n T_{0}}{S_{2}^{2}-\mathrm{S}_{1}^{2}} \log \left(\frac{\omega^{2}+S_{2}^{2}}{\omega^{2}+S_{1}^{2}}\right)^{1 / 2} * W^{2}(\omega)
$$

と表される. また, $r=2$ の時は,

$$
\begin{aligned}
E_{4}(\omega)= & \frac{3 \overline{A^{2}} n T_{0}}{S_{2}^{3}-S_{1}^{3}}\left[S_{2}-S_{1}-\omega\right. \\
& \left.\times\left(\tan ^{-1} S_{2} / \omega-\tan ^{-1} S_{1} / \omega\right)\right] * W^{2}(\omega)
\end{aligned}
$$

である.

エネルギースペクトル $E_{3}, E_{4}$ は，時系列が充分に長 く, $\omega \rightarrow 0$ のとき,

$E_{3} \rightarrow 2 \overline{A^{2}} n T_{0} /\left(S_{2}^{2}-S_{1}^{2}\right) \log \left(S_{2} / S_{1}\right)$

$E_{4} \rightarrow 3 \overline{A^{2}} n T_{0} /\left(S_{1}^{2}+S_{1} S_{2}+S_{2}^{2}\right)$

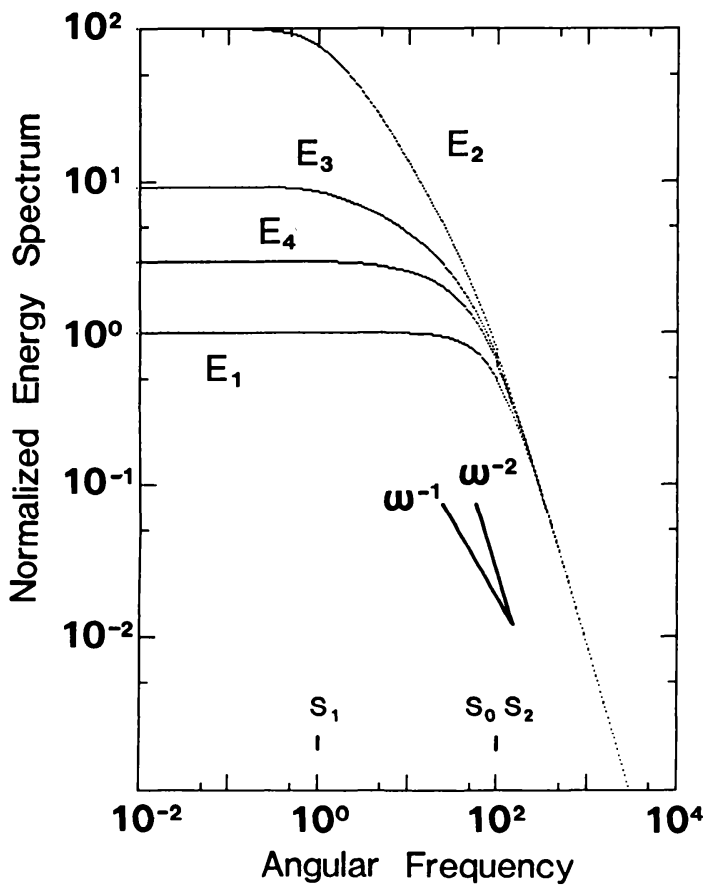

Fig. 5. Energy spectrum of the random-pulse time series. The maximum relaxation coefficient of $S_{2}$ is assumed $10^{2}$ in this case. All the others are the same as those in Fig. 3. Note that $E_{2}$ spectrum in between two corner frequecies shows a fractal spectrum of $1 / f^{1+\delta}$ decay, where $\delta$ is a small fractional number.

となり，それぞれ一定の值となる．また， $\omega \gg 1$ のとき は,

$$
\begin{aligned}
& E_{3}(\omega) \simeq \overline{A^{2}} n T_{0} / \omega^{2} \\
& E_{4}(\omega) \simeq \overline{A^{2}} n T_{0} / \omega^{2}
\end{aligned}
$$

で表される.

(13), (18), (24), (25) の結果から, どの確率密度の場合 でも, 高い周波数帯でエネルギースペクトルのふるまい は同じになっている.これは高い周波数帯でのスペクト ルがパルスの立ち上がりの形状だけで決まり, 緩和時間 や確率密度に依存しないからであると考えられる。ま た, 低い周波数帯では, ランダム波動の平均的な性質を 見ていることになる. したがって，スペクトルは，無相 関の白色スペクトルを与えている.

\section{4. エネルギースペクトルのフラクタル構造}

前節ではパルス減衰定数（緩和時間の逆数）S の確率 密度を考え, ランダムな時系列のエネルギースペクトル の表現式を具体的に導いた. Fig. 3 に, $S_{0}=10^{2}, S_{1}=1$, $S_{2}=10^{4}$, としたとき, 各々のエネルギースペクトルを計 
算し，スペクトル振幅 $\overline{A^{2} n} T_{0} / S_{0}^{2}$ で規格化して示す. Fig. 4 に, $S_{0}$ と $S_{1}$ が Fig. 3 と同じ場合で, $S_{2}=10^{3}$ とし たときのエネルギースペクトルを示す. Fig. 5 に, $S_{0}=$ $10^{2}, S_{1}=1, S_{2}=10^{2}$ である場合の例を示す.すべての場 合で時系列の継続時間が充分に長く, ウインドーの効果 を(11) 式で形式的に評価して考えている. 以後の議論で は，常に $S_{1}=1$ と仮定してある．したがって，周波数は 任意の $S_{1}$ の值で規格化されていると考えてよい.

スペクトル振幅の折れ曲がり点を表す周波数をコー ナー周波数という [BRUNE (1970)]. ローレンッ型のス ペクトル $E_{1}(\omega)$ は $S_{0}$ がコーナー周波数にあたる. ここ で一つ注意したいのは, 我々が議論しているスペクトル は短周期のランダム波動のスペクトルであるから，そこ に現れるコーナー周波数はBRUNE (1970)などにより旧 来からいわれているコヒーレントな長周期地震波に現れ るコーナー周波数ではないことである．断層全体の破壊 時間から決まる長周期地震波のコーナー周波数は，いう なれば，決定論的な（巨視的な）パラメーターである. 本論文でのコーナー周波数は, 断層の不均質領域（断層 パッチ）の平均破壊時間の逆数で決まる短周期の波動ス ペクトルに特徴的に現れるパッチコーナー周波数 [小山 (1983), Kоуама (1985)] であると考えられる. パッチ コーナー周波数は, 不均質な断層破壊を記述する新しい 概念により導入された確率論的な（微視的な）パラメー タである [小山(1983)].したがって，この意味では， パッチコーナー周波数は微視的な素過程を特徵づける緩 和時間の逆数と考えられ，特別な場合は，ブラウン運動 する粒子の平均自由時間の逆数と考えてもよい［小山 (1988b)]. 以後すべてのコーナー周波数は短周期波動に 特有なパッチコーナー周波数と読み変えて議論を進め る. 長周期波動に現れるコーナ一周波数とははっきりと 違うものである.

减衰定数の分布が $S_{1}$ から $S_{2}$ の区間で一様な場合のス ペクトル $E_{2}$ は, $S_{1}$ で決まる低い周波数帯之 $S_{2}$ で決まる 高い周波数帯に 2 つコーナ一周波数を持つことがわ かる. また， $E_{2}$ のふるまいは, $S_{1}$ から $S_{2}$ の周波数帯で $\omega^{-1}$ に比例して減衰している (Fig. 3).これは AGU and Kinoshit A (1977) と同じである.ただし， $S_{1}$ と $S_{2}$ の值 が接近すると， $E_{2}$ のふるまいは，スペクトルの傾きが緩 やかに変化し， $\omega^{-(1 \sim 2)}$ で咸衰するスペクトルになる (Fig. 4, Fig. 5). このふるまいは, 小さな数 $\delta$ を導入し, $\omega^{-(1+\delta)}$ と表すことができる.つまり, 確率変数が一様分 布で与えられているとき，そのスぺクトル減衰のべき係 数は, 非整数次を示す周波数領域があり, それは 2 つの コーナ一周波数 $S_{1}$ と $S_{2}$ の相対的な大きさの違いによっ て決っている.
以後, 上のようにスペクトルが周波数の自乗より小さ な整数次・非整数次のべき乗に反比例して減衰すると きそれをフラクタル的なスペクトルと呼ぶことにす る.

$E_{3}$ は, $S_{1}$ に対応するコーナ一周波数が存在する．スペ クトルは, 非常に緩やかに減衰し, コーナ一周波数 $S_{2}$ 付 近で $E_{1}$ スペクトルに漸近する． $E_{4}$ は，スペクトル振幅 を別にすれば，コーナー周波数が $S_{2}$ となるローレンツ 型のスペクトルとほとんど同様なスペクトルである． $E_{3}$ や $E_{4}$ の計算に用いた確率密度は $S$ とともに増加する傾 向があり (Fig. 2), 高い周波数のスペクトル成分が卓越す る.このことから，減衰定数の確率密度が特定の範井に 集中したり，特微的な減衰定数が存在する場合，その時 系列はローレンッ型のスペクトルを示すことがわかる.

\section{5.特殊な確率分布（カントール集合）のスペクトル 構造}

SHLESINGER and HUGHES (1981) はカントール集合型 待ち時間分布でランダムインパルスが生起する確率過程 を考えている，カントール集合とは，確率事象の数が 2 のべき乗となる自己相似な関数で表される集合である. 地震の断層破壊は階層的で, 破壊領域の大きさ分布は離 散的であるとする考え方がある [FUKAO and FURUMOTO (1985), Hara and OKayama (1988), Ito (1985)]. 今ま で考えた連続型の確率密度とは異なり, 確率変数か離散 值を取る場合について考える。

SHLESINGER and Hughes (1981) は時系列のフラクタ ル的性質を明らかにしたが，そのスペクトル構造のふる まいを明らかにしていない，ここでは，彼らとは独立に， カントール集合から作り出されるランダムな時系列を考 え，そのエネルギースペクトルを解析的に導き，スペク トル構造の性質を考えてみる. Fig. 6 にカントール集合 を棒の長さで示す，始めの長さが 1 で，それを 3 等分し て 2 個取り出す.この操作を繰り返し，いろいろな長さ の棒の分布を作る. $m$ 回目の分割で，カントール棒の長 さは $3^{-m}$ であり， $2^{m}$ 個ある. この棒の長さをパルスの 緩和時間の長さと考えて，ランダムパルスの母集合をつ くる．このランダムパルスを任意に取り出し，パルスの 緩和時間ごとに時間軸上にならべた時系列を考える (Fig. 6). 簡単のため, パルスの立ち上がり振幅は土1で あり，正負等確率であるとする．Fig. 1 と同様に，各八゚ ルスの振幅は指数関数で咸衰し, 発生するパルスは互い に無相関であるものとする. パルスの個数は, Fig. 6 に 示す分割の $m$ 段目で $2^{m}$ 個である。そそれに対応する減衰 定数は,

$S=3^{m}$ 

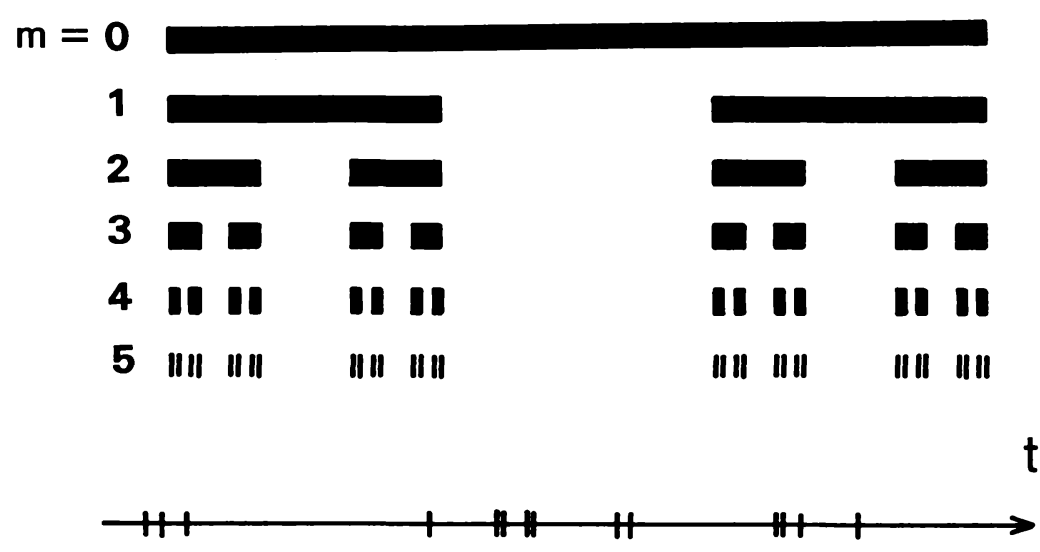

\section{Time Interval by Cantor Set}

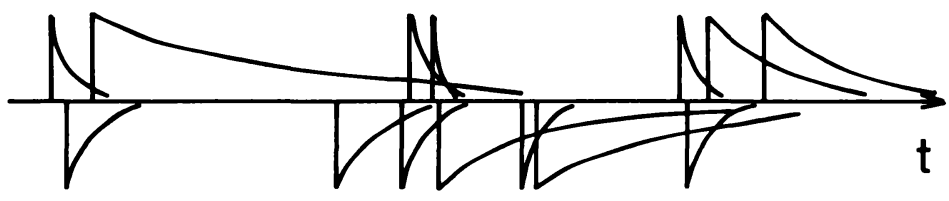

Random Pulse Series by Cantor Set

Fig. 6. Time interval generated by the Cantor bar. The middle third of each segment is cut out in each subdivision. The longest interval between points of the set occurs $2^{0}$ times, which is assumed to be 1.0 in this case. The next longest interval is a factor of $3^{1}$ smaller and occurs $2^{1}$ times. The interval of $m$-th subdivision is $3^{m}$ times smaller than the longest interval and occurs $2^{m}$ times as often. Random time series is generated by the random pulses with relaxation times given by the above Cantor set of bars. Positive and negative impulses with unit amplitude are equally probable, thence, generating a random-pulse time series with zero mean and random phases.

となる.したがって, $m$ 段目のカントール棒で特徴づけ られた $i$ 番目のパルスは,

$$
\begin{aligned}
F_{m}^{(i)}(\omega)= & \alpha_{m}^{(i)} \exp \left(-i \omega t_{m}^{(i)}\right) /\left(i \omega+3^{m}\right) \\
& \left(i=1,2, \ldots, 2^{m}\right)
\end{aligned}
$$

のスペクトルを持ち, $2^{m}$ 個存在する. ただし， $\alpha_{m}^{(i)}$ はイン パルスの振幅で,ここでは土1の值をとるとする. また, $t_{m}^{(i)}$ はパルスの発生時刻である. 最大 $M$ 段目までの分割 でできるカントール棒の集合を考えるとき, 総パルス数 が

$$
n T_{0}=\sum_{m=0}^{M} 2^{m}
$$

である. エネルギースペクトルは， $\alpha_{m}= \pm 1$ を考えると $\overline{A^{2}}=1$ となり,

$$
E_{5}(\omega)=\sum_{m=0}^{M} \frac{2^{m}}{\omega^{2}+3^{2 m}} * W^{2}(\omega)
$$

で表される. 時系列が充分に長く, $\omega \rightarrow 0$ の極限では,

$$
E_{5} \rightarrow\left\{1-(2 / 9)^{M+1}\right\} /(1-2 / 9)
$$

となり,一定值に漸近する. また, $\omega \gg 1$ の高い周波数帯 では,

$$
E_{5}(\omega) \simeq\left(2^{M+1}-1\right) / \omega^{2}
$$

である.この結果は § 3 で述べたいくつかの確摔密度の 場合と同様なふるまいである。

Fig. 7(a) に分割のステップ数 $M$ が 5, 8,11, 14, 17, 20 の場合について，カントール集合のパルスから生起する ランダム波動のエネルギースペクトルを示す、スペクト ルは明らかに 2 つのコーナ一周波数を持つ.1つは低い 周波数帯のコーナー周波数で, $\omega=1$ である.これは最 大の緩和時間で決まる最小減衰定数 $S=1$ に対忘してい る. 分割数の $M$ が大きくなると, 短い緩和時間のパルス が数多くなる．それに連れて，最大の分割数で決まる高 い周波数側のコーナー周波数もより高い周波数へ移る.

Fig. 7(a) から，2 つのコーナー周波数の間ではおおよそ $\omega^{-4 / 3}$ 程度でスペクトルは減少している。 そのスペクト ル減衰の傾きは, 緩和時間の分布か狭いほよ゙, 分割数が 小さいほど, わずかに大きい傾向にある.

緩和時間がカントール集合型待ち時間で表現される Fig. 6 のパルス波動は, 自己相似性を示す.そのエネル ギースペクトルは 2 より小さなべき乗で減衰するフラ 


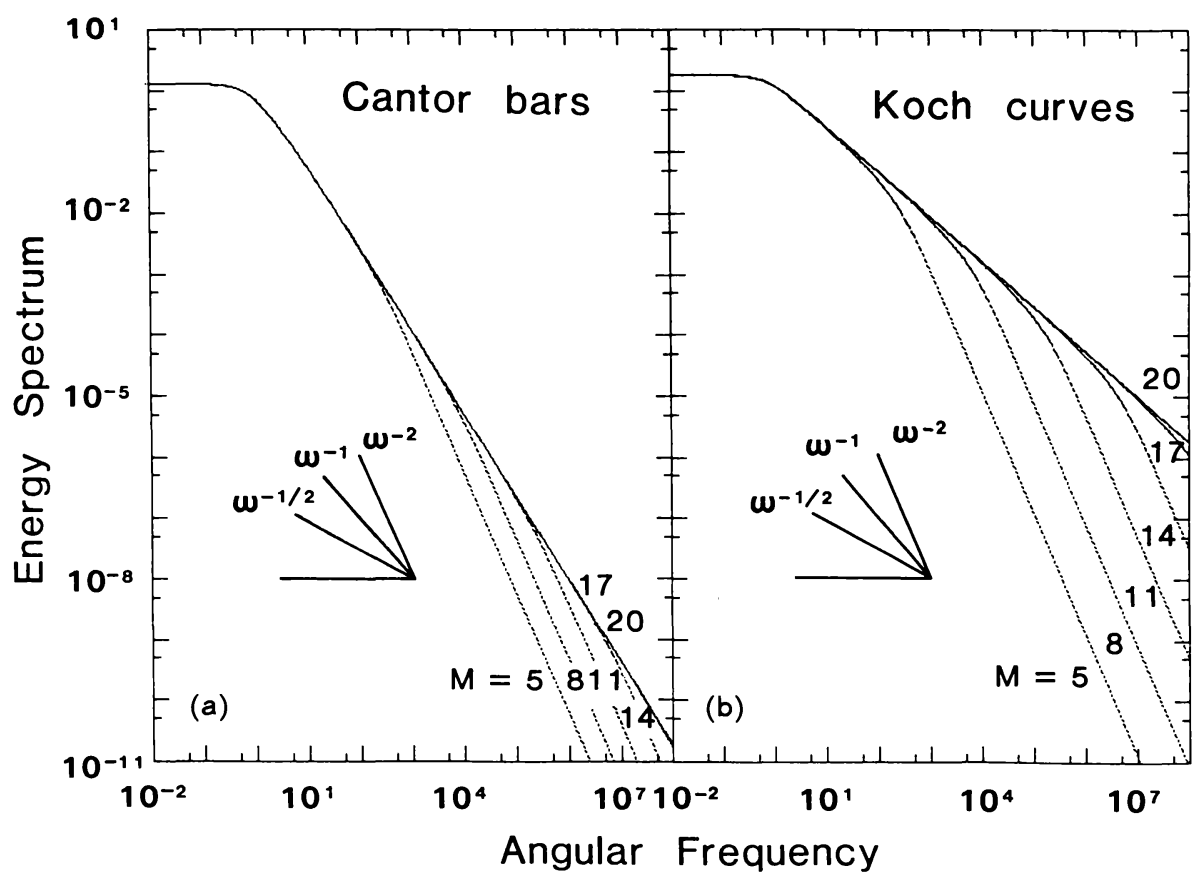

Fig. 7. Energy spectrum of the random-pulse time series with self similar distributions. (a) Randompulses by the relaxation times specified by the Cantor set. Subdivision levels of Cantor bars of $5,8,11$, 14,17 and 20 are considered. The spectral corner frequency of about 1.0 is found in the spectra, which corresponds to the longest relaxation time. The other corner frequency is found and it relates to the minimum relaxation time. Spectral decay in between these two corner frequencies is about $4 / 3$, suggesting a fractal spectrum. (b) Random-pulses by the relaxation times specified by the Koch curves. Two corner frequencies are also found like as (a). The spectral decay in between the above corner frequencies is measured about $3 / 4$.

クタル的なふるまいを示すことがわかる. 分割数の $M$ が十分大きいとき, $S=3^{m}$ の変数変換で (28) 式を (9) 式 のような積分形に書き換えることができる。これによ り, 形式的にカントール集合の寄せ集めから生じる確率 密度 $P_{5}(S)$ は,

$$
P_{5}(S) \simeq \gamma S^{\gamma-1} / S_{2}^{\gamma}
$$

で表されることがわかる，ただし， $S_{2}$ はパルス減衰定数 の最大值 $3^{M}$ である. また, $S_{2} \gg S_{1}$ だから $S_{1} \approx 0$ とし た.

$$
\gamma=\log 2 / \log 3
$$

である.ここで， $P_{5}$ の定数因子は区間 $\left[S_{1}, S_{2}\right]$ 規格化条 件から決めた.この確率密度は $S$ の変化に比べてゆっく りと変化し，それは 3.3 に述べたべき分布よりも一様分 布の確率密度のふるまいに近い.

\section{6.一般化カントール分布のスペクトル構造}

Fig. 6 に描いたカントール集合は, $\log 2 / \log 3$ のフ ラクタル次元である [SHLESINGER and Hughes (1981)]. このカントール集合を一般化して, はじめの長さが 1
で，それを $k$ 等分した長さのカントール棒を $j$ 個 $(<k)$ 取り出す操作を考える. 2 段目以降の分割では, 前の段 のカントール棒を同様に分割し，それを繰り返し，いろ いろな長さの棒からできる集合を考える.ここでは，こ の長さの分布を一般化カントール分布と呼ぶことにす る. この一般化カントール分布から，1 より大きな整数 $j$ と $k$ の組合せで,

$$
\gamma=\log j / \log k \quad(k>j)
$$

の断続的に任意のフラクタル次元を持つ分布を作り出せ ることが理解される. また, 分割の数 $M$ が大きいとき, (31) と (32) 式からこの分布の 2 次モーメントは,

$$
\gamma /(\gamma+2) S_{2}^{2}
$$

で近似される.

整数次のべき分布や，一般化カントール分布から作り 出されるランダム波動のエネルギースペクトルを計算す る. Fig. 8 にそのスペクトル減衰の傾きを調べ，それぞ れの確率密度分布の 2 次モーメントで図示する. 2 次 モーメントは, 整数次のべき分布では解析的に, 一般化 カントール分布では (33) 式から計算する. スペクトルの 


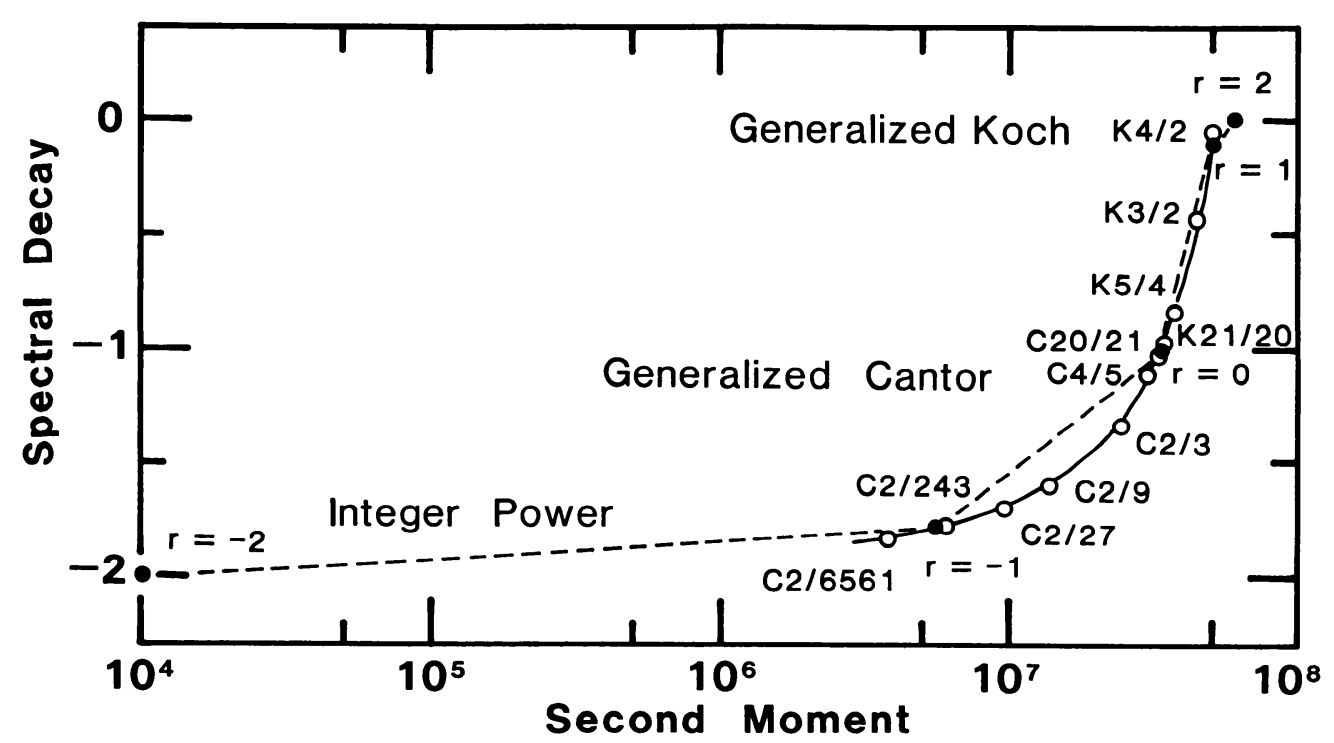

Fig. 8. Spectral decay in terms of second moment of probability density distribution. Integer power distributions and the distributions of the generalized Cantor bars and the generalized Koch curves are considered. The maximum and miminum relaxation coefficients of $S_{2}=10^{4}$ and $S_{1}=1$ are assumed in the numerical calculations. The value of $r$ from -2 to 2 indicates the integer power for the probability density distribution. C2/6561, for example, indicates the generalized Cantor set with fractal dimension of $\log 2 / \log 6561$. K instead of $\mathrm{C}$ stands for the generalized Koch cuves. The spectral decay is measured on each energy spectrum plot, so that it is an empirical value and no longer a rigorous rational.

傾きは, Fig. 3 で述べたように，2つの特徴的なコー ナ一周波数 $S_{1}$ と $S_{2}$ の周波数帯で考えている. ただし, $S_{1}$ と $S_{2}$ の値はそれぞれ, 1 と $10^{4}$ と仮定した. 2 次モ一 メントの值によってスペクトルの傾きが大きく変化して いる. 一般化カントール分布からスペクトル減衰の傾き が-1 から-2 の間の非整数次の数で得られることがわ かる.

カントール集合は, Fig. 6 からあわかるようにいたる ところに不連続点が存在する. (32) 式でカントール分割 $(j<k)$ とは違う, $j>k$ の場合を考えよう。例えば, $j=4$, $k=3$ の時, はじめの長さを 1 として, その線分の長さを 3 等分し, 4 個の線分を取り出し考える場合に対応する. この操作を繰り返し行うと, Fig. 9 に示すようなコッホ 曲線と呼ばれる図形を作ることができる， $m$ 段のコッホ 曲線の線分の長さは, $3^{-m}$, その折れ線の数は $4^{\mathrm{m}}$ であ る. 整数 $j$ と $k(j>k)$ を任意に選ぶことで, 一般化カン トール分布の場合と同じに, Fig. 9 のコッホ曲線も一般 化できる. ランダムパルスの緩和時間の分布が任意に抽 出したコッホ曲線の線分の長さで離散的に与えられると きを考える.コッホ曲線の線分の長さをパルス幅とする ランダムパルスの時系列からそのスペクトル表現式, フ ラクタル次元, 分散などを計算すると, 一般化カントー
ル分布の場合と同様に与えられる. Fig. 7 (b) に $j=4$, $k=3$ の場合について, エネルギースペクトルを計算し た. スペクトル減衰のべき係数は約 $3 / 4$ である.このよ うに, 一般化カントール分布之一般化したコッホ曲線の 分布から得られるエネルギースペクトルの表現には本質 的な違いがないことがいえる.

$r=1$ や 2 の整数次のべき分布では, スペクトルの減 衰が非常に小さい.これらは Fig. 4 や Fig. 5 でローレ ンツ型に近いスペクトル構造を示していた. 確率密度が 短周期側にかたより，高い周波数帯のスペクトル成分が 卓越したスペクトル構造を示している. その結果, 低い 周波数側のコーナ一周波数はおおいかくされてしまって いる. Fig. 8 で $j=4, k=2$ とした一般化したコッホ曲線 の分布の $\mathrm{K} 4 / 2$ の例でも同様の傾向を示す.一般に, $j>$ $k^{2}$ の組合せから生じる一般化したコッホ曲線の分布か らは上の場合と同様に, 高い周波数側のコーナー周波数 だけが常に卓越して現れる. 一般化したコッホ曲線の分 布からスペクトル減衰の傾きが 0 から-1 の間で得られ る.

一方, $r=-2$ の分布から得られるスペクトルは, 低い 周波数側のコーナー周波数だけが強調されている.これ も確率密度の形状から先の議論とは逆に, 低い周波数帯 


\section{$\mathrm{m}=0$}

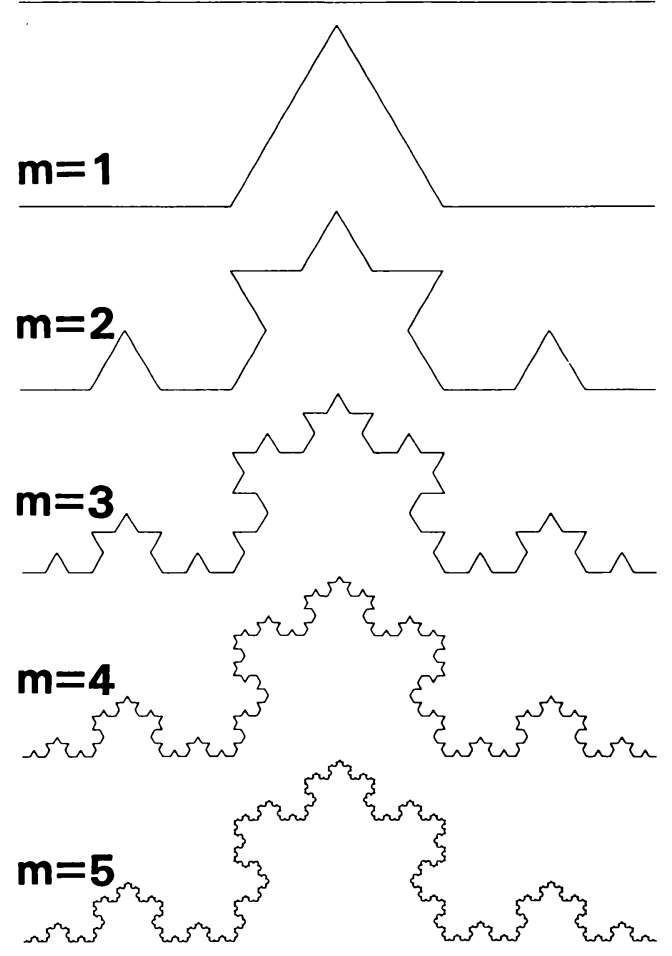

Fig. 9. The Koch curves specify the time intervals and the number of events. Time series is generated by the random pulses with the relaxation times given by the above Koch curves. The interval of $m$-th subdivision is $3^{m}$ times smaller than the longest interval and occurs $4^{m}$ times as often. This may be generalized, taking integers of $j$ instead of 3 and $k$ in place of 4 , where $j>k>1$.

のスペクトル成分が卓越したエネルギースペクトルであ ると理解される。はじめの長さが 1 の線分を 6561 等分 して，その中から 2 個だけ取り出す操作の一般化カン トール分布をC $2 / 6561$ と記した. Fig. 8 でこのスペク トルは低い周波数帯のスペクトルが卓越したふるまいを している.さらに，j《kとなる一般化したカントール分 布の場合は, $r=-2$ の結果へ漸近する.

カントール集合やコッホ曲線の分布は自己相似な分布 を与える. その確率事象の発生数は 2 のべき乗個や整数 $j$ のべき乗個である. このような自己相似であるパルス の母集合から作り出されるランダム時系列が常にフラク タル的なスペクトルを示すわけではないことが上に示し た結果から理解される，スペクトル構造をきめるのは, (9) 式の積分で表されているように, 事象の発生数では なく, 各事象の発生確率である. 確率密度は, 見かけ上
現れる発生数とは違い，(31) 式で表される，そして，非 整数次で咸衰するスペクトル構造のふるまいは確率密度 分布の形状に依存していることが結論される.

\section{7. 議論}

Gruneis and Musha (1986) は, 1/f スペクトルとな る確率過程を考えている。彼らは，ランダム事象として インパルスが次々に集中して起こるクラスターをポアッ ソン過程で励起した場合を，一般的に取り扱っている。 $1 / f$ スペクトルを生み出すのは, 単一のランダム過程で はなく，ポアッソン過程とランダムな長さを持つクラス 夕一の生成過程がいっしょになった複合過程であると考 えている. 本研究では, 最初に, ランダムな振幅のイン パルスで立ち上がるランダムな継続時間のパルスで複合 過程を考えたが，ランダムパルスの時系列では複合過程 であることが $1 / f$ スペクトルにそれほよ゙重要ではない. むしろ $1 / f$ スペクトルを与えるのは，ランダムパルスの 継続時間の確率密度が一様分布に近いようなランダム過 程でなければいけないことがわかった。

ここでは指数関数的に振幅が滅衰するパルスを考えて いるから，ローレンッ型のスペクトルが現れている．箱 型のパルスを考えれば，スペクトルの包絡線がローレン ツ型で近似される [小山(1983)]。 ランダムウォークを 定式化するには，後者のパルスが現実的であるが，前者 の関数型は取り扱いが容易で見通しがよい．したがっ て, 本論で得られたローレンツ型のスペクトルは形式的 な結果であり，同様のスペクトル形状は別の素過程を考 えても得られる.

Fig. 4 や Fig. 5 の確率密度では, 分散だけが違ってい る.この違いが, スペクトルのふるまいに周波数 $f$ で， $1 / f^{1+\delta}$ となる変化を与えていると考えられる． ス ペクトル減衰係数 $\delta$ は確率密度のひろがり（分散）に関 係していることが指摘される。 むちろん，分散とフラク タル次元は直接関係しているから，フラクタル次元でこ の結論をいい換えても良い。しかし，素過程の確率密度 が例えば正規分布であるなどのように知れている現象の フラクタル次元はあまり意味がない。したがって，より 一般的にはここで述べた分散（2次モーメント）で記述 するのがよいと考える.

過渡的な現象ではよ゙のような確率密度分布であって も, 有限個の事象しか観測されないのだから，平均値己 その分散が定義される．一様分布では，時系列の継続時 間 $T_{0}$ が大きくなるとき，抽出される減衰定数の範囲の 広がり，その平均值の分散が大きくなる，ガウス分布な どでは逆に，平均値のまわりをサンプルする数が増える 分だけ, 分散の不偏推定量は小さくなることが期待され 
る. ランダム現象のスペクトルのコーナー周波数は確率 密度の存在範囲から決まり，スペクトルの形状や減衰の 傾きは確率密度の関数形に依存する.したがって, 長時 間の時系列サンプルから得られるスペクトル構造はラン ダム波動を励起する素過程の統計的な性質を強く反映し ていることがわかる.

有限時間の観測は物理的な制約であり, 確率密度分布 に観測可能な上限 $S_{2}$ と下限 $S_{1}$ を与える. そして, $S_{1}$ や $S_{2}$ がフラクタルスペクトル構造の周波数領域での特徴 的なコーナー周波数になっていることを示した. 先に述 べた GRUNEIS and MUSHA (1986) は，スペクトルが $1 / f$ となる周波数帯域は有限で, それは, インパルス群の最 小継続時間と最大継続時間に対応する周波数で決まるこ とを導いている.インパルス群の継続時間をパルスの緩 和時間と読みかえれば，ここでの考え方と同じであろ j.

ランダムパルスの緩和時間は, 地震学的には, ランダ 么破壊する断層パッチの大きさ（その破壊継続時間）に 強く関係する [KOYAMA (1985)]. ここでの議論はエネル ギースペクトルであり, 直接一般的な震源スペクトルに 結び付かない. しかし, 形式的に断層の全体的な大きさ を，断層の幅が破壊する時間 $T_{0}$ と長さ方向の破壊時間 $\tau_{0}$ で考虑すれば,

$\left\{E_{i}(\omega) \sin ^{2}\left(\omega \tau_{0} / 2\right) /(\omega / 2)^{2}\right\}$

で震源エネルギースペクトルを表現できる[KoYAMA (1985)]. この場合, 単位時間に観測されるパルスの数 $n$ は $T_{0}$ に比例する. 単位時間当りに発生するパルスの数 を $\rho$ とすると, 断層面全体では, $\rho T_{0} \tau_{0}$ 個の断層パッチ が破壊することになる. $\tau_{0}$ は $S_{1}$ などの特徵的なコー ナー周波数の逆数より充分大きいから, 震源エネルギー スペクトルの減衰はおよそ $E_{\mathrm{i}}(\omega) / \omega^{2}$ と考えればよい.

これをもとに, フラクタルスペクトル構造と地震の短周 期震源スペクトル構造を考えてみよう.

ここで結論できるのは, $\omega^{-1} や \omega^{-(1+\delta)}$ の非整数次で 減衰するエネルギースペクトルはランダムパルスの減衰 定数が一様分布かそれに近いような確率密度のときに限 られることである. 断層パッチ内での破壊伝播速度があ まり変化しないと考えれば，断層パッチのサイズ分布が 一様分布に近いときが, フラクタル的なスペクトルのふ るまいを与えると考えても良いだろう。このとき，(34) 式の平方根で定義する震源スペクトルは, $1 / \omega^{1.5} \sim$ $1 / \omega^{1.5+\delta / 2}$ となる.

一様分布だからといって小さな断層パッチの数が大き な断層パッチの数と同じであるわけではない，例えば, (32) 式のカントール集合の結果から, 単位長さを $k$ 分割 し, そのすべての $k$ 個が $1 / k$ の長さを持つ断層パッチ
とすれば, $k$ 分の 1 の長さとなる断層パッチは $k$ 個, $k^{m}$ 分の長さとなる断層パッチは $k^{m}$ 個存在する. 断層パッ チの個数は $k$ のべき乗で増加する．しかし，断層パッチ が $k$ 分の 1 の長さとなる確率と $k^{m}$ 分の 1 の長さである 確率は共に等しい. そして, その確率密度は $m$ が充分大 きいとき一様分布の近似になることを考えれば理解され る.

大地震の破壊過程を考える場合, それが断層破壊の長 さや幅といった空間的に絶対的な拡がりを持っことか ら，(34) 式の導入で考えたように，震源エネルギースペ クトルは断層の大きさから決まる特定の波数をもつロー レンツ型のスペクトルで表される。断層面が不均質でラ ンダムな短周期波動を励起するときは, さらに，(34) 式 のエネルギースペクトルとの和で表されるエネルギース ペクトルなることが導かれている[小山(1988b)].つま り，一般的に震源スペクトルとして導かれているローレ ンツ型をした震源スペクトル [KoyAmA et al. (1982), TAKEMURA and KOYAMA (1983)] は, 決定論的であるマ クロな震源パラメータで決まる部分と断層パッチのエネ ルギー放出がガウス分布かそれに近い密度分布をする不 均質な微小破壊のミクロなパラメータで決まる部分から 得られていることになる. スペクトル構造の見かけのふ るまいが同じであっても，その素過程は全然違うものの 例である. GRUNEIS and MUSHA (1986) は, この違いを 物理現象のコヒーレント時間と個々のランダムな継続時 間とで区別して考え, どちらの場合でもローレンッ型の スペクトルが得られることを示している. 断層全体の破 壊継続時間（コーナ一周波数）とゆらいでいる断層パッ チの破壊継続時間（パッチコーナー周波数 [小山 (1983)]）を考えれば，ここでの議論と対応づけられる.

\section{8. 結論}

従来, いろいろな空間図形とか点や線の空間分布など の複雑な性質を考えて, そのスペクトル構造のフラクタ ル性が議論されてきた. ここでは, 時系列解析の立場か らランダム波動のエネルギースペクトル構造とその素過 程の確率密度を詳しく調へたた. 周波数を $f$ とすると, $1 / f$ や $f$ の非整数次で減衰するエネルギースペクトルはラン ダムパルスの継続時間が一様分布かそれに近いような確 率密度分布をするときに発生していることがわかった。 さらに, フラクタル的なスペクトル構造を支配する物理 則は確率事象の個数ではなく, その確率密度でより一般 的に理解されることが示された. $1 / f^{1+\delta}$ となる非整数ス ペクトルのふるまいでは, $\delta$ がフラクタル次元, より一 般的には, 確率変数の分散 (2 次モーメント) に関係し ていることが示される。 
ランダム波動のスペクトルからわかるコーナー周波数 はランダム事象の確率密度の存在範囲に強く依存し, ス ペクトルの傾きや形状は確率密度の関数形に関係してい る.この研究は確率過程が持つ性質がどのようにランダ ム波動に反映されるのかを明らかにし，長時間の時系列 サンプルから微細な素過程がどのようにマクロな現象へ 発展しているのかを調べる理論的な基礎を与えるもので あると考える，その一例として，不均質な大断層が破壊 するとき励起される短周期地震波が, 震源での素過程の 確率論的性質によ゙のように依存しているのかを議論し た.

\section{謝 辞}

本研究費の一部は文部省科学研究費重点領域 (63601005)によった。

\section{文献}

Agu, M., and T. Kinoshita, 1977 , On $1 / f$ spectrum of randomly superposed relaxation processes, Proceeding of symposium on $1 / f$ fluctuations, Tokyo, 41-48.

Blackman, R. B., and J. W. Turkey, 1958, The measurement of power spectra, Dover Pub., New York, pp. 83-116.

BRUNE, J. N., 1970, Tectonic stress and the spectra of seismic shear waves from earthquakes, J. Geophys. Res., 75, 4997-5009.

Fukao, Y. and M. Furumoto, 1985, Hierarchy in earthquake size distribution, Phys. Earth Planet. Inter., 37, 149-168.

Gruneis, F., and T. Musha, 1986, Clustering Poisson process and $1 / f$ noise, Jap. J. App. Phys., 25, 15041509.

Hara, H., and S. Okayama, 1988, Fractal dimension and scaling behavior of cracks in a random medium: "Frequency-rank" distribution described by generalized random walks, Phys. Rev. B, 37, 9504-9511.
Iто, A., 1985, A study on microearthquake swarms on the basis of milli-second hypocenter determination, 東北大学博士学位論文, $211 \mathrm{pp}$.

小山順二, 1983, 伝播性破壊確率モデルと地震の震源ス ペクトル, 地震 2, 36, 225-235.

小山順二，1984, 伝播性破壊確率モデルと短期地震波の 励起, 地震 2, 37, 295-305.

Koy AмA, J., 1985, Earthquke source time-function from coherent and incoherent rupture, Tectonophysics, 118, 227-242.

小山順二, $1988 \mathrm{a}$, 不均質な断層の破壊と大地震が励起 する強震動, 数理地震学 (III), 統計数理研究所, 224247.

小山順二, $1988 \mathrm{~b}$, 伝播性破壊確率モデルと最大加速 度 $\cdot r m s$ 加速度, 地震 $2,41,351-357$.

Koyama, J. and Y. Izutani, 1988, Seismic excitation and directivity of short period body waves from a stochastic fault model, Tectonophysics, in press.

Koyama, J., and N. Shimada, 1985, Physical basis of earthquake magnitudes: An extreme value of seismic amplitudes from incoherent fracture of random fault patches, Phys. Earth Planet. Inter., 40, 301-308.

Koy ama, J., and S.-H. Zheng, 1985, Excitation of short-period body-waves by great earthquakes Phys. Earth Planet. Inter., 37, 108-123.

Koyama, J., M. Takemura, and Z. Suzuki, 1982, A scaling model for quantification of earthquakes in and near Japan, Tectonophysics, 84, 3-16.

大内 徹, 1988, 震源過程に関する数理的考察 (2)一フラ クタル的震源の確率モデルとその地震波スペクトル 一, 地震 2, 41, 71-78.

ShLEsinger, M. F., and B. D. Hughes, 1981, Analogs of renormalization group transformations in random processes, Physica, 109A, 597-608.

高安秀樹, 本田勝也, 佐野雅巳, 田崎晴明, 村山和郎, 伊東敬祐, 1987, フラクタル科学, 朝倉書店, pp. 285.

Takemura, M. and J. Koyama, 1983, Seismic source spectrum of tsunami and ordinary earthquakes: $A$ quantitative estimation of tsunami from forecoming seismic waves, Tohoku Geophys. J., 29, 115-128. 